\title{
Pioglitazone Inhibits Growth of Carcinoid Cells and Promotes TRAIL-Induced Apoptosis by Induction of p21waf1/cip 1
}

\author{
Rüdiger Göke ${ }^{a}$ Alexandra Göke ${ }^{a}$ Burkhard Göke ${ }^{b}$ Wafik S. El-Deiry ${ }^{c}$ \\ Youhai Chen ${ }^{a}$ \\ aDepartment of Molecular and Cellular Engineering, and ${ }^{b}$ Department of Medicine, University of Pennsylvania \\ School of Medicine, Philadelphia, Pa., USA; 'Department of Internal Medicine II, Klinikum Grosshadern, \\ University of Munich, Germany
}

\section{Key Words}

Pioglitazone · Carcinoid · TRAIL · Apoptosis · p21waf1/cip1

\begin{abstract}
Background/Aims: We investigated the effect of the peroxisome proliferator-activated receptor- $\gamma$ (PPAR- $\gamma$ ) agonist pioglitazone on growth and TRAIL-induced apoptosis in carcinoid cells. Methods: Carcinoid cells were incubated without and with pioglitazone. Effects on growth were examined by cell count and cell cycle analysis. p21waf1/cip1 expression was determined by Western blotting. Cytotoxicity assay was performed by FACS analysis. Results: Pioglitazone suppressed the growth and induced apoptosis of carcinoid cells. Additionally, pioglitazone significantly enhanced carcinoid cell death induced by tumor necrosis factor (TNF)-related apoptosisinducing ligand (TRAIL). The enhancement of TRAILinduced apoptosis was associated with an upregulation of cyclin-dependent kinase inhibitor p21waf1/cip1 in pioglitazone-treated carcinoid cells. Importantly, overexpression of p21waf1/cip1 in carcinoid cells by adenoviral gene transfer of p21 sensitized them to TRAIL-induced apoptosis. Conclusions: These results suggest that pioglitazone inhibits cell growth and sensitizes cells to TRAIL-induced apoptosis by induction of p21waf1/cip1. Therefore, pioglitazone can be an effective therapeutic adjuvant for the treatment of carcinoid tumors.
\end{abstract}

Copyright @ 2001 S. Karger AG, Basel

\begin{tabular}{ll}
\hline KARGER & ( ) 2001 S. Karger AG, Basel \\
Fax + 4161306 1234 & \\
$\begin{array}{l}\text { E-Mail karger@karger.ch } \\
\text { www.karger.com }\end{array}$ & $\begin{array}{l}\text { Accessible online at: } \\
\text { www.karger.com/journals/dig }\end{array}$
\end{tabular}

\section{Introduction}

Tumor necrosis factor (TNF)-related apoptosis-inducing ligand (TRAIL) is a newly identified member of the TNF family [1]. It shares the highest sequence homology with Fas (CD95, Apo-1) ligand, another member of the TNF family that is capable of inducing apoptosis. However, in contrast to Fas ligand (FasL), TRAIL induces apoptosis of a variety of tumor cells, but not normal cells [2]. To date, five different receptors for TRAIL have been identified: i.e. Death Receptor 4 (DR4, TRAIL-R1), Death Receptor 5 (DR5, TRAIL-R2), Decoy Receptor 1 (DcR1, TRAIL-R3, TRID), Decoy Receptor 2 (DcR2, TRAIL-R4, TRUNDD), and osteoprotegerin. Binding of TRAIL to either DR4 or DR5 recruits FADD to its intracellular death domain and activates the caspase cascade resulting in cell death $[3,4]$. DcR 1 and DcR2 are decoy receptors that do not transduce apoptotic signals but may protect cells from TRAIL-induced apoptosis [5-8]. Osteoprotegerin is the only known soluble receptor for TRAIL, which has been reported to regulate osteoclastogenesis [9].

Pioglitazone is an antidiabetic thiazolidinedione that specifically activates the nuclear transcription factor PPAR- $\gamma$. PPAR- $\gamma$ exists in two isoforms, PPAR- $\gamma 1$ and PPAR- $\gamma 2$ [10]. While PPAR- $\gamma 2$ is expressed primarily in adipocytes, PPAR- $\gamma 1$ has been identified in a variety of tissues $[10,11]$. It has been reported that PPAR- $\gamma$ plays

\footnotetext{
Dr. Rüdiger Göke

Clinical Research Unit, University of Marburg

Baldingerstrasse

D-35033 Marburg (Germany)

Tel. +215 898 4671, Fax +215 573 8606, E-Mail rgoeke@gmx.net
} 
important roles in lipid metabolism and inflammation [10] and that activation of PPAR- $\gamma$ induces apoptosis of differentiated macrophages and macrophages activated by TNF- $\alpha$ or interferon- $\gamma$ [12]. We have recently reported that PPAR- $\gamma$ regulates TRAIL-induced apoptosis of Jurkat T cells and colon cancer cells (HT-29 and SW480) [13]. In this report, we studied the effect of pioglitazone on the growth and apoptosis of carcinoid cells, and discovered a novel role for cyclin-dependent kinase inhibitor $\mathrm{p} 21^{\text {waf } 1 / \text { cip } 1}$ in TRAIL-induced apoptosis. Treatment of endocrine tumors is extremely challenging because they are resistant to chemotherapy and radiation and show only a limited sensitivity to hormones and cytokines such as somatostatin or interferon- $\alpha$ [14]. Data reported here suggest that a combination of TRAIL and pioglitazone may be effective in treating these tumors.

\section{Materials and Methods}

\section{Cell Lines and Reagents}

NCI-H727 carcinoid cells were cultured in RPMI 1640 medium supplemented with $10 \%$ fetal bovine serum and $1 \%$ penicillin/streptomycin. Pioglitazone (Takeda, Osaka, Japan) was dissolved in dimethyl sulfoxide (DMSO) and added to the cell culture to a final concentration of $20 \mu \mathrm{M}$. Control cultures received the same amount of DMSO (which was less than $0.2 \%$ of the medium).

\section{$R T-P C R$}

Total RNA was extracted from cells using the RNeasy kit, and reverse transcribed to cDNA using the Omniscript cDNA synthesis kit with hexamer primers (Quiagen, Valencia, Calif., USA) per manufacturer's instructions. For detection of PPAR- $\gamma$ mRNA, the following primers were used: Sense primer, 5'-TCTCTCCGTAATGGAAGACC-3', and antisense primer, 5'-GCATTATGAGACATCCCCAC-3' [15]. PCR amplification was performed using Taq polymerase (Promega, Madison, Wisc., USA) under the following conditions: Denaturation at $95^{\circ} \mathrm{C}$ for $2 \mathrm{~min}$, amplification for 35 cycles $\left(95^{\circ} \mathrm{C}\right.$ for $45 \mathrm{~s}, 55^{\circ} \mathrm{C}$ for $1 \mathrm{~min}$ and $72^{\circ} \mathrm{C}$ for $\left.1 \mathrm{~min}\right)$, and extension at $72^{\circ} \mathrm{C}$ for $7 \mathrm{~min}$. The PCR products were then separated by electrophoresis on a $1 \%(\mathrm{w} / \mathrm{v})$ agarose gel containing ethidium bromide.

\section{Cell Cycle Analysis}

Cells were cultured in $75 \mathrm{~cm}^{2}$ cell culture flasks with or without $20 \mu M$ pioglitazone for 4 days. Cells were then harvested, and fixed in ice-cold $70 \%(\mathrm{v} / \mathrm{v})$ ethanol for $24 \mathrm{~h}$ at $4^{\circ} \mathrm{C}$. After centrifugation $\left(2,000 \mathrm{~g}, 4^{\circ} \mathrm{C}, 4 \mathrm{~min}\right)$, the cell pellet was resuspended in phosphatebuffered saline (PBS) ( $\mathrm{pH} 7.4$ ) containing $1 \mu \mathrm{g} / \mathrm{ml}$ of DNase-free RNase, $50 \mu \mathrm{g} / \mathrm{ml}$ of propidium iodide (PI) and $0.1 \%$ glucose. Cells were incubated at room temperature in the dark for $4 \mathrm{~h}$, and DNA content was determined by flow cytometry using a FACScan flow cytometer (Becton-Dickinson, San Jose, Calif., USA). Histograms were analyzed using the ModFit 2.0 software (Verity Software House, Topsham, Me., USA).

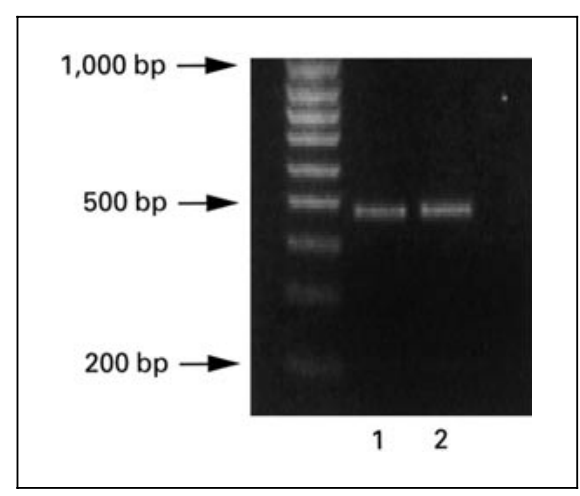

Fig. 1. PPAR- $\gamma$ expression in NCI-H727 carcinoid cells and HT-29 colon cancer cells. Total RNA was extracted and RT-PCR was performed as described in 'Methods'. PPAR- $\gamma$ expression (474 bp) in NCI-H727 and HT-29 cells is shown in lanes 1 and 2, respectively.

\section{Cytotoxicity Assay}

Cells were pre-incubated in 24-well plates with or without pioglitazone for various times followed by an incubation with or without recombinant human TRAIL (Biomol, Plymouth Meeting, Pa., USA) for $16 \mathrm{~h}$ at $37^{\circ} \mathrm{C}$. Cells were then harvested, washed and resuspended in PBS (pH 7.4) containing $1 \mathrm{~m} M$ glucose and $2 \mu \mathrm{g} / \mathrm{ml}$ of propidium iodide. PI fluorescence intensity was determined by flow cytometry using a FACScan flow cytometer.

\section{Western Blot Analysis}

Cell lysates were first separated by polyacrylamide gel electrophoresis. The $\mathrm{p} 21^{\text {wafl/cip } 1}$ protein was then detected by Western blotting [16] using an anti-p2 $1^{\text {wafl/cip } 1}$ antibody (clone SXM30) from Pharmingen (San Diego, Calif., USA).

\section{Results}

\section{Pioglitazone Inhibits Growth of Carcinoid Cells by Blocking Cell Cycle Progression}

PPAR- $\gamma$ is constitutively expressed in a variety of cell types $[17,18]$. To determine whether PPAR- $\gamma$ is expressed in carcinoid cells, we tested its gene expression in NCI-H727 cells by PCR. As shown in figure 1, PPAR- $\gamma$ mRNA is readily detectable in NCI-H727 cells as well as HT-29 colon cancer cells which are known to express high levels of PPAR- $\gamma$ mRNA [19].

To determine the effect of PPAR- $\gamma$ activation on the growth of NCI-H727 carcinoid cells, we treated them with $20 \mu M$ pioglitazone for up to 8 days. As shown in figure $2 \mathrm{a}$, treatment with pioglitazone significantly inhibited the proliferation of carcinoid cells. This was associated 

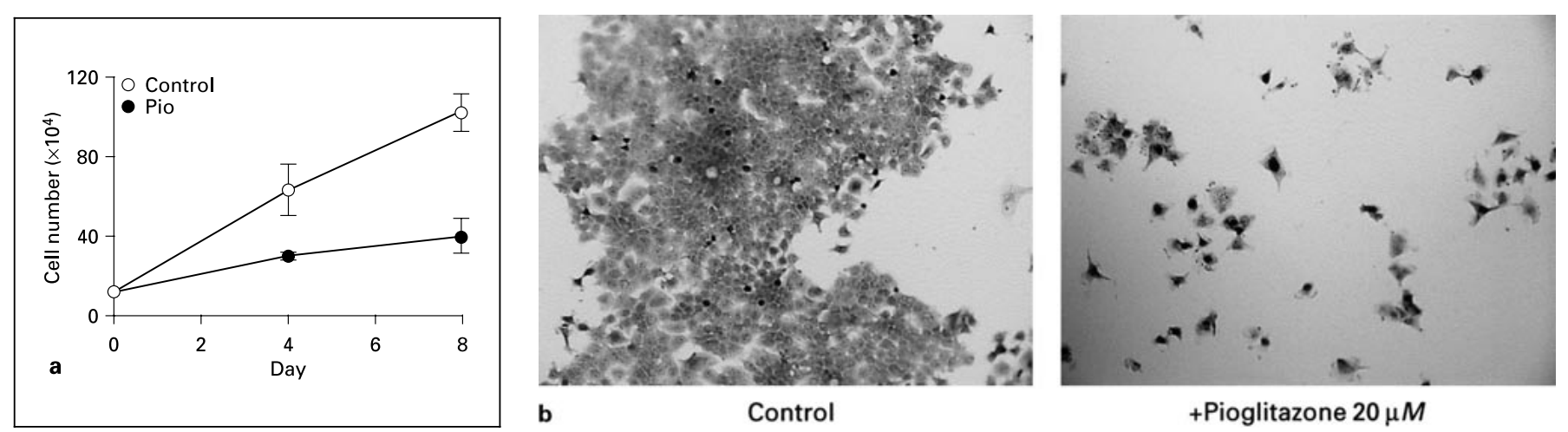

Fig. 2. a Pioglitazone inhibits growth of NCI-H727 carcinoid cells. $1.25 \times 10^{4}$ cells were cultured with or without 20 $\mu M$ pioglitazone for up to 8 days. The number of cells in each culture was determined using a Rosenthal counting chamber. Data presented are means of duplicated cultures of a representative experiment. b Pioglitazone inhibits cell growth and prevents colonization of NCI-H727 cells. NCI-H727 cells were cultured with or without $20 \mu M$ pioglitazone for 4 days, stained with hematoxylin/eosin, and examined by light microscopy. Original magnification $\times 200$.

with a reduced ability of these cells to colonize (fig. $2 b$ ). Further analysis of these cells revealed significant blockade of cell cycle progression by pioglitazone (fig. 3). Specifically, pioglitazone increased the percentage of cells in the G0/G1 phase while it decreased the percentage of cells in the $\mathrm{S}$ phase of the cell cycle (fig. 3).

\section{Pioglitazone Enhances TRAIL-Induced Apoptosis of \\ Carcinoid Cells}

To determine whether PPAR- $\gamma$ plays any role in TRAIL-induced apoptosis of carcinoid cells, we pretreated NCI-H727 cells with $20 \mu M$ pioglitazone for 4 days and then examined their sensitivity to TRAILinduced apoptosis. As shown in figure 4, TRAIL alone induced moderate apoptosis of these cells, suggesting that they are sensitive to TRAIL-induced apoptosis. Pretreatment of these cells with pioglitazone significantly increased their sensitivity to TRAIL-induced apoptosis, with the percentage of apoptotic cells increased by 3 -fold in the pioglitozone-treated group (fig. 4). Pioglitozone alone also induced detectable apoptosis of carcinoid cells, which is consistent with reports of the effect of PPAR- $\gamma$ agonists on other cell types [15, 20].

Fig. 3. Effect of pioglitazone on cell cycle progression in NCI-H727 cells. NCI-H727 cells, $10^{6}$ cells $/ \mathrm{ml}$, were cultured with or without $20 \mu M$ pioglitazone for 4 days. Cells were then harvested, fixed in $70 \%$ ethanol, and stained with propidium iodide. The percentage of cells in each phases of cell cycle was determined by flow cytometry using the ModFit 2.0 software.

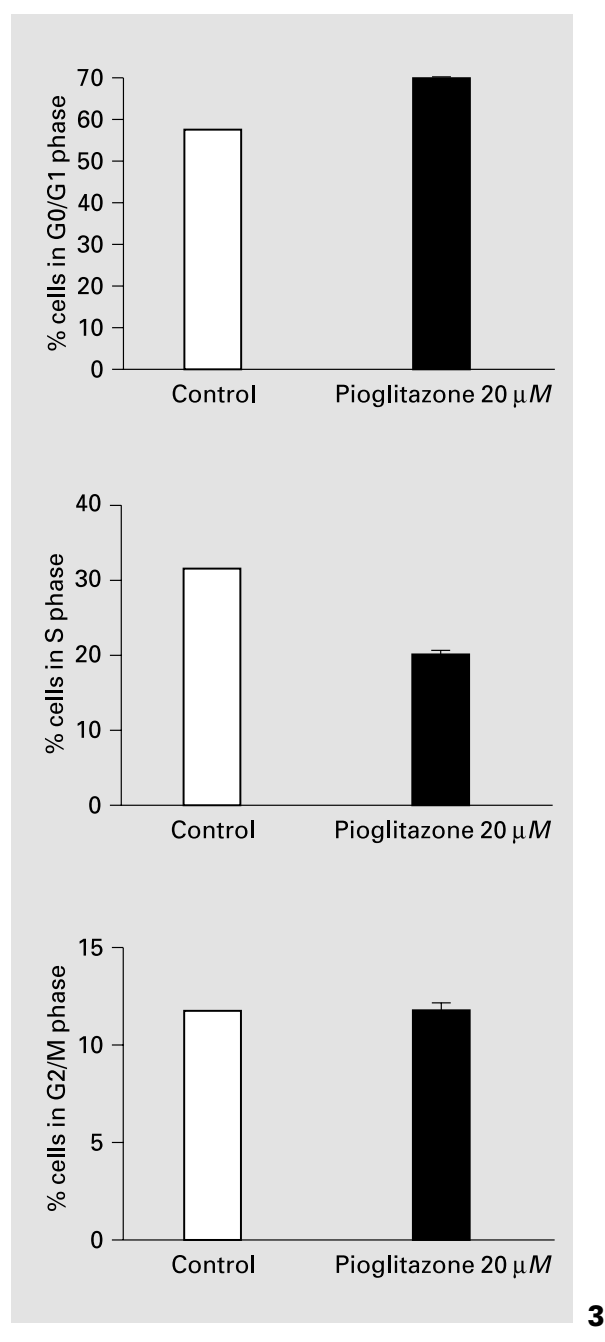



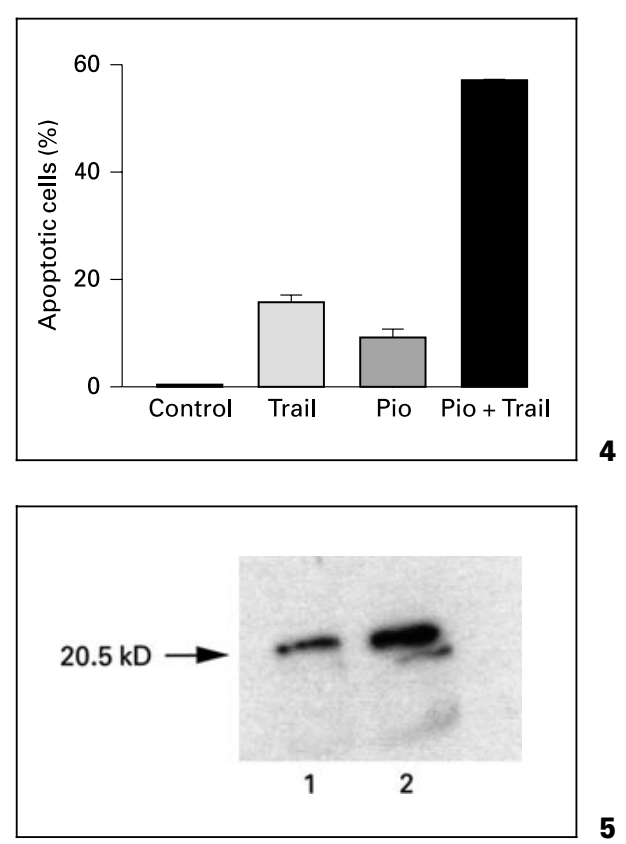

Fig. 4. Pioglitazone enhances TRAIL-induced apoptosis of NCIH727 cells. NCI-H727 cells, $5 \times 10^{5}$ cells $/ \mathrm{ml}$, were cultured with or without $20 \mu M$ pioglitazone for 4 days. Cells were then treated with $200 \mathrm{ng} / \mathrm{ml}$ of TRAIL for $16 \mathrm{~h}$. The percentage of apoptotic cells was determined by flow cytometry as described in Methods. Data presented are means \pm SEM of the percentages of apoptotic cells pooled from two experiments. Control cells were treated with vehicle alone. Pio $=$ Pioglitazone .

Fig. 5. Pioglitazone induces $\mathrm{p} 21^{\text {waf } 1 / \mathrm{cip} 1}$ expression in NCI-H727 cells. NCI-H727 cells, $10^{6}$ cells $/ \mathrm{ml}$, were cultured with $20 \mu M$ pioglitazone for 4 days. Proteins were extracted and $\mathrm{p} 21^{\text {waf } 1 / \mathrm{cip} 1}$ protein was detected by Western blot analysis. Each lane was loaded with $50 \mu \mathrm{g}$ protein. Lane $1=$ Cells treated with vehicle; lane $2=$ cells treated with pioglitazone.

\section{p21 $1^{\text {wafl/cipl }}$ Expression Promotes TRAIL-Induced Apoptosis in Carcinoid Cells}

Recently, it was reported that the PPAR- $\gamma$ agonist troglitazone upregulates the cyclin-dependent kinase inhibitor $\mathrm{p} 21^{\text {waf } 1 / \text { cip } 1}$ in several tumor cell lines [21]. However, the role of $\mathrm{p} 21^{\text {waf } 1 / \mathrm{cip} 1}$ in apoptosis is unclear. Several reports suggest that $\mathrm{p} 21^{\text {wafl/cip } 1}$ may prevent cell death [22-24]. On the other hand, Fas (CD95) ligation in T cells induces expression of $\mathrm{p} 21^{\text {wafl/cip } 1}$ and promotes Fasinduced apoptosis [25].

To explore the potential roles of $\mathrm{p} 21^{\text {waf } 1 / \text { cip } 1}$ in TRAILinduced apoptosis and its regulation by PPAR- $\gamma$, we examined the effect of PPRA- $\gamma$ on $\mathrm{p} 21^{\text {wafl/cip } 1}$ expression
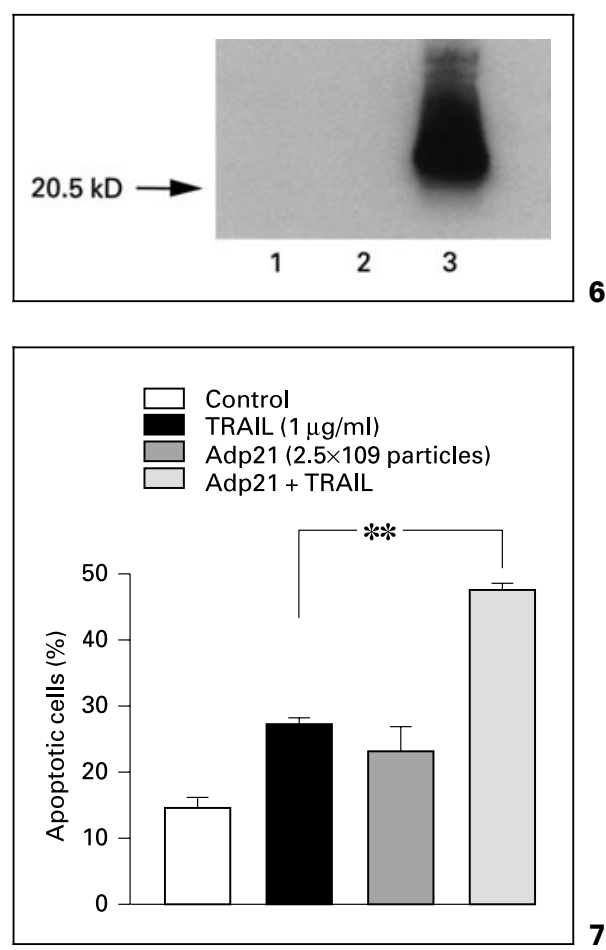

Fig. 6. Expression of $\mathrm{p} 21^{\text {wafl/cip } 1}$ in NCI-H727 cells infected with Adp2 $1^{\text {waf } 1 / \mathrm{cip} 1}$. NCI-H727 cells, $10^{6}$ cells $/ \mathrm{ml}$, were infected with $2.5 \times 10^{9}$ particles of Adp2 $1^{\text {waf } 1 / \text { cipl }}$ (lane 3 ). Control cells were either noninfected (lane 1) or infected with $2.5 \times 10^{9}$ particles of AdLacZ (lane 2). Proteins were extracted and $\mathrm{p} 21^{\text {waf } 1 / \mathrm{cip} 1}$ was detected by Western blot analysis. Each lane was loaded with $50 \mu \mathrm{g}$ protein.

Fig. 7. Overexpression of $\mathrm{p} 21^{\text {waf } 1 / \mathrm{cip} 1}$ enhances TRAIL-induced apoptosis. NCI-H727 cells, $10^{6}$ cells $/ \mathrm{ml}$, were either infected or not infected with $2.5 \times 10^{9}$ particles of Adp2 $1^{\text {waf } 1 / \text { cip } 1.24}$ h later, cells were cultured with or without TRAIL $(1 \mu \mathrm{g} / \mathrm{ml})$ for an additional $16 \mathrm{~h}$. The percentage of apoptotic cells was determined by flow cytometry as described in 'Methods'. Data presented are means \pm SEM of percentages of apoptotic cells pooled from two experiments. $* * \mathrm{p}<0.005$ as determined by ANOVA.

and its impact on TRAIL-induced apoptosis. As shown in figure $5, \mathrm{p} 21^{\text {waf } 1 / \mathrm{cip} 1}$ expression was significantly increased in carcinoid cells treated with $20 \mu M$ pioglitazone. This may explain the cell cycle arrest induced by pioglitazone as shown in figure 3. To directly examine the effect of upregulated $\mathrm{p} 21^{\text {waf1/cip } 1}$ expression on TRAIL-induced apoptosis, we infected carcinoid cells with a recombinant adenovirus carrying the $\mathrm{p} 21^{\text {wafl/cip } 1}$ gene. As shown in figure 6 , expression of $\mathrm{p} 21^{\text {waf } 1 / \mathrm{cip} 1}$ was dramatically increased in cells infected with $\mathrm{p} 21^{\text {waf } 1 / \text { cip } 1}$ virus, but not the control virus. Since the exposure time of the film was only $10 \mathrm{~s}$, basal expression of p21 was not detectable in controls. Figure 5 shows that basal p21 expression in controls 
is detectable after an exposure time of $1 \mathrm{~min}$. Importantly, overexpression of $\mathrm{p} 21^{\text {waf } 1 / \mathrm{cip} 1}$ significantly increased the sensitivity of these cells to TRAIL-induced apoptosis (fig. 7).

\section{Discussion}

TRAIL is a newly described member of the TNF superfamily, which shares the highest homology with FasL. However, unlike FasL, TRAIL selectively kills transformed tumor cells, but not most nontransformed normal cells. Putative mechanisms responsible for the TRAIL resistance include the expression of TRAIL decoy receptors on the cell surface and/or expression of antiapoptotic genes such as FLIP, IAP or survivin in resistant cells [26-28]. Expression of anti-apoptotic or survival genes may be regulated by transcription factors such as NF- $\kappa$ B and PPAR- $\gamma$ [29]. We have previously reported that TRAIL-induced apoptosis in Jurkat cells and colon cancer cells is regulated by these transcription factors. Activation of the nuclear receptor PPAR- $\gamma$ or inhibition of NF- $\kappa \mathrm{B}$ resulted in an increased sensitivity of cells to TRAIL-induced apoptosis [13]. Encouraged by these results and other studies demonstrating a pro-apoptotic effect of thiazolidinediones on tumor cells [15, 20], we investigated the effect and the mechanisms of action of a PPAR- $\gamma$ agonist in TRAIL-induced apoptosis using a carcinoid cell line, NCI-H727. NCI-H727 cells were originally derived from a lung carcinoid tumor and are the best-characterized carcinoid cells. We found that pioglitazone inhibits the growth of NCI-H727 cells by blocking G1-to-S phase cell cycle progression and sensitizes them to TRAIL-induced apoptosis. Furthermore, we demonstrated that pioglitazone upregulates the expression of cyclin-dependent kinase inhibitor $\mathrm{p} 21^{\text {waf } 1 / \mathrm{cip} 1}$, which in turn is capable of sensitizing carcinoid cells to TRAILinduced apoptosis. To our knowledge, this is the first report on the role of $\mathrm{p} 21^{\text {wafl/cip } 1}$ in TRAIL-induced apoptosis.

Several reports suggest that thiazolidinediones alone are capable of inducing apoptosis of tumor cell lines [15, 20]. Although the precise pro-apoptotic actions of these substances remain to be elucidated, PPAR- $\gamma$-mediated inhibition of $\mathrm{NF}-\kappa \mathrm{B}$ has been suggested to be involved $[13,30]$. Results reported here indicate that the cyclindependent kinase inhibitor $\mathrm{p} 21^{\text {waf } 1 / \text { cip } 1}$ may also play an important role in this process. $\mathrm{p} 21^{\mathrm{waf} 1 / \mathrm{cip} 1}$ is involved in multiple biological functions including the inhibition of cyclin-dependent kinases, which results in suppression of cell cycle progression [31]. However, the roles of p2 $1^{\text {waf } 1 / \text { cip } 1}$ in apoptosis are poorly understood. Previous reports suggest that $\mathrm{p} 21^{\text {waf1/cip } 1}$ may play an anti-apoptotic role by inhibiting cyclin-dependent kinases, or by regulating the functions of caspases, stress-activated kinases, or survival genes [32]. On the other hand, it has also been shown that overexpression of $\mathrm{p} 21^{\text {waf } 1 / \mathrm{cip} 1}$ promotes apoptosis of BHK21 cells [33]. Our results suggest that p2 $1^{\text {waf1/cip } 1}$ expression enhances TRAIL-induced apoptosis in carcinoid cells. This is consistent with a recent report that $\mathrm{p} 21^{\text {waf } 1 / \mathrm{cip} 1}$ promotes Fas-induced apoptosis in $\mathrm{T}$ cells [25]. However, it is unclear whether the apoptotic activity of $\mathrm{p} 21^{\mathrm{waf} 1 / \mathrm{cip} 1}$ is resulted from its effect on cell cycle. In this regard, it has been reported that although the transcription factor E2F regulates both cell cycle and apoptosis [34, 35], the two functions are not mutually dependent on each other [36]. Since p $21^{\text {waf1/cip } 1}$ has been shown to directly interact with the transcription factor E2F [37], it is conceivable that it may promote the apoptotic effect of the E2F while inhibit its effect on cell cycle.

Treatment of neuroendocrine tumors remains extremely challenging. In the case of carcinoid tumors, surgery is rarely curative and external radiation therapy has not been successful [14]. Similarly, carcinoid tumors respond poorly to chemotherapy with only a small fraction of them responding to streptozotocin, doxorubicin or 5-fluorouracil [38, 39]. Somatostatin analogues inhibit the release of peptide hormones from neuroendocrine tumors attenuating clinical symptoms. However, tumor reduction is observed only in less than $10 \%$ of patients treated with somatostatin analogues [40, 41]. Finally, although $50 \%$ of the patients with carcinoid tumors respond to interferon- $\alpha$ therapy, only about $15 \%$ of them show significant tumor shrinkage [41]. Data reported here suggest that pioglitazone inhibits growth of carcinoid cells and sensitizes them to TRAIL-induced apoptosis. Thus, a combination of pioglitazone and TRAIL may be an effective therapeutic regimen for the treatment of carcinoid tumors.

\section{Acknowledgements}

This work was supported by grants from the National Institutes of Health, USA (NS40188 and AR44914). R.G. is a fellow of the Heisenberg program of the Deutsche Forschungsgemeinschaft (DFG). The support of the DFG is gratefully appreciated.

Digestion 2001;64:75-80 


\section{References}

1 Wiley SR, Schooley K, Smolak PJ, Din WS, Huang CP, Nicholl JK, Sutherland GR, Smith TD, Rauch C, Smith CA, Goodwin RG: Identification and characterization of a new member of the TNF family that induces apoptosis. Immunity $1995 ; 3: 673-682$

2 Walczak H, Miller RE, Ariail K, Gliniak B, Griffith TS, Kubin M, Chin W, Jones J, Woodward A, Le T, Smith C, Smolak P, Goodwin RG, Rauch CT, Schuh JC, Lynch DH: Tumoricidal activity of tumor necrosis factor-related apoptosis-inducing ligand in vivo. Nat Med 1999;5:157-163.

3 Pan G, O'Rourke K, Chinnaiyan AM, Gentz R, Ebner R, Ni J, Dixit VM: The receptor for the cytotoxic ligand TRAIL. Science 1997;276: 111-113.

4 Wu GS, Burns TF, McDonald ER III, Jiang W, Meng R, Krantz ID, Kao G, Gan DD, Zhou JY, Muschel R, Hamilton SR, Spinner NB, Markowitz S, Wu G, El-Deiry WS: Killer/DR5 is a DNA damage-inducible p53-regulated death receptor gene. Nat Genet 1997;17:141143.

5 Sheridan JP, Marsters SA, Pitti RM, Gurney A Skubatch M, Baldwin D, Ramakrishnan L, Gray CL, Baker K, Wood WI, Goddard AD Godowski P, Ashkenazi A: Control of TRAILinduced apoptosis by a family of signaling and decoy receptors. Science 1997;277:818-821.

6 Degli-Espost MA, Smolak PJ, Walczak H, Waugh J, Huang CP, DuBose RF, Goodwin RG, Smith CA: Cloning and characterization of TRAIL-R3, a novel member of the emerging TRAIL receptor family. J Exp Med 1997;186: 1165-1170.

7 Degli-Esposti MA, Dougall WC, Smolak PJ, Waugh JY, Smith CA, Goodwin RG: The novel receptor TRAIL-R4 induces NF-kB and protects against TRAIL-mediated apoptosis, yet retains an incomplete death domain. Immunity $1997 ; 7: 813-820$.

8 Pan G, Ni J, Yu G, Wei YF, Dixit VM: TRUNDD, a new member of the TRAIL receptor family that antagonizes TRAIL signaling. FEBS Lett 1998;424:41-45.

9 Emery JG, McDonnell P, Burke MB, Deen KC, Lyn S, Silverman C, Dul E, Appelbaum ER, Eichman C, DiPrinzio R, Dodds RA James IE, Rosenberg M, Lee JC, Young PR Osteoprotegerin is a receptor for the cytotoxic ligand TRAIL. J Biol Chem 1998;273:1436314367.

10 Tontonoz P, Hu E, Graves RA, Budavari AI, Spiegelman BM: mPPAR gamma 2: Tissuespecific regulator of an adipocyte enhancer. Genes Dev 1994;8:1224-1234.

11 Tontonoz P, Hu E, Devine J, Beale EG, Spiegelman BM: PPAR gamma 2 regulates adipose expression of phosphoenolpyruvate carboxykinase gene. Mol Cell Biol 1995;15:351-357.

12 Chinetti G, Griglio S, Antonucci M, Torra IP, Delerive P, Majd Z, Fruchart JC, Chapman J, Najib J, Staels B: Activation of proliferatoractivated receptors alpha and gamma induces apoptosis of human monocyte-derived macrophages. J Biol Chem 1998;273:25573-25580.
13 Göke R, Göke A, Göke B, Chen Y: Regulation of TRAIL-induced apoptosis by transcription factors. Cell Immunol 2000;201:77-82.

14 Öberg K: Carcinoid tumors: Current concepts in diagnosis and treatment. Oncologist 1998;3: 339-345.

15 Takahashi N, Okumura T, Motomura W, Fujimoto Y, Kawabata I, Kohgo Y: Activation of PPAR-gamma inhibits cell growth and induces apoptosis in human gastric cancer cells. FEBS Lett 1999;455:135-139.

16 Ramalingam A, Hirai A, Thompson EA: Glucocorticoid inhibition of fibroblast proliferation and regulation of the cyclin kinase inhibitor p21Cip1. Mol Endocrinol 1997;11:577586.

17 Braissant O, Foufelle F, Scotto C, Dauca M, Wahli W: Differential expression of peroxisome proliferator-activated receptors (PPARs): Tissue distribution of PPAR-alpha, -beta and -gamma in the adult rat. Endocrinology 1996; 137:354-366.

18 Greene ME, Blumberg B, McBride OW, Yi HF, Kronquist K, Kwan K, Hsieh L, Greene G, Nimer SD: Isolation of the human peroxisome proliferator activated receptor gamma cDNA: Expression in hematopoietic cells and chromosomal mapping. Gene Expr 1995;4:281-299.

19 Sarraf P, Mueller E, Jones D, King FJ, DeAngelo DJ, Partridge JB, Holden SA, Chen LB, Singer S, Fletcher C, Spiegelman BM: Differentiation and reversal of malignant changes in colon cancer through PPAR g. Nat Med 1998; 4:1046-1052.

20 Tsubouchi Y, Sano H, Kawahito Y, Mukai S, Yamada R, Kohno M, Inoue K, Hla T, Kondo $\mathrm{M}$ : Inhibition of human lung cancer cell growth by the peroxisome proliferator-activated receptor-gamma agonists through induction of apoptosis. Biochem Biophys Res Commun 2000; 270:400-405.

21 Sugimura A, Kiriyama Y, Nochi H, Tsuchiya H, Tamoto K, Sakurada Y, Ui M, Tokumitsu Y: Troglitazone suppresses cell growth of myeolid leukemia cell lines by induction of p21waf/1cip1 cyclin-dependent kinase inhibitor. Biochem Biophys Res Commun 1999;261: 833-837.

22 Suzuki A, Tsutomi Y, Akahane K, Araki T, Miura M: Resistance to Fas-mediated apoptosis: Activation of caspase- 3 is regulated by cell cycle regulator $\mathrm{p} 21 \mathrm{waf} 1$ and IAP gene family ILP. Oncogene 1998;17:931-939.

23 Polyak K, Waldman T, He TC, Kinzler KW, Vogelstein B: Genetic determinants of p53induced apoptosis and growth arrest. Genes Dev 1996;10:1945-1952.

24 Gorospe M, Wang X, Guyton KZ, Holbrook NJ: Protective role of p21(waf1/cip1) against prostaglandin A2-mediated apoptosis of human colorectal carcinoma cells. Mol Cell Biol 1996;16:6654-6660.

25 Hingorani R, Bi BY, Dao T, Bae Y, Matsuzawa A, Crispe IN: CD95/Fas signaling in T-lymphocytes induces the cell cycle control protein p21 cip1/waf1, which promotes apoptosis. J Immunol 2000;164:4032-4036.
26 Irmler M, Thome M, Hahne M, Schneider P, Hofmann K, Steiner V, Bodmer J-L, Schröter M, Burns K, Mattman C, Rimoldi D, French LE, Tschopp J: Inhibition of death receptor signals by cellular FLIP. Nature 1997;388:190195.

27 Deveraux QL, Reed JC: IAP family proteins Suppressors of apoptosis. Genes Dev 1999;13: 239-252.

28 Ambrosini G, Adida C, Altieri DC: A novel anti-apoptosis gene, survivin, expressed in cancer and lymphoma. Nature Med 1997;3:917921

29 Bours V, Bentires-Alj M, Hellin A-C, Viatour $\mathrm{P}$, Robe P, Delhalle S, Benoit V, Merville M-P: Nuclear factor-kB, cancer, and apoptosis. Biochem Pharmacol 2000;60:1085-1090.

30 Ricote M, Li AC, Wilson TM, Kelly CJ, Glass $\mathrm{CK}$ : The peroxisome proliferator-activated receptor-g is a negative regulator of macrophage activation. Nature 1998;391:79-82.

31 Xiong Y, Hannon GJ, Zhang D, Casso R, Kobayashi R, Beach D: p21 is a universal inhibitor of cyclin kinases. Nature 1993;366: 701-704.

32 Dotto GP: p21waf1/cip1: More than a break to the cell cycle? Biochim Biophys Acta 2000; 1471:M43-M56.

33 Sekiguchi T, Hunter T: Induction of growth arrest and cell death by overexpression of the cyclin-Cdk inhibitor p21 in hamster BHK21 cells. Oncogene 1998;16:369-380.

34 Jooss K, Lam EW, Bybee A, Girling R, Muller $\mathrm{R}$, La Thangue NB: Proto-oncogenic properties of the DP family proteins. Oncogene 1995;10: 1529-1536.

35 Field S, Tsai FY, Kuo A, Zubiaga AM, Kaelin WG Jr, Livingston DM, Greenberg ME: E2F-1 functions in mice to promote apoptosis and suppress proliferation. Cell 1996;85:549-561.

36 Phillips AC, Bates S, Ryan KM, Helin K, Vousden KH: Induction of DNA synthesis and apoptosis are separable functions of E2F-1. Genes Dev 1997;11:1853-1863.

37 Delavaine L, La Thangue NB: Control of E2F activity by p21waf1/cip1. Oncogene 1999;18: 5381-5392.

38 Moertel CG,Hanley JA: Combination chemotherapy trials in metastatic carcinoid tumor and the malignant carcinoid syndrome. Cancer Clin Trials 1979;2:327-334.

39 Norheim I, Öberg K, Alm G: Treatment of malignant carcinoid tumors: A randomized study of streptocotocin plus 5-FU and human leukocyte interferon. Eur J Cancer Clin Oncol 1989;25:1475-1479.

40 Vinik AL ,Moattari AR: Use of somatostatin analog in management of carcinoid syndrome. Dig Dis Sci 1989;34:14S-27S.

41 Öberg K, Norheim I, Theodorsson E: Treatment of malignant midgut carcinoid tumors with a long-acting somatostatin analog octreotide. Acta Oncol 1991;4:503-507. 